\title{
Krystyna Wiesława Trembicka, Wrogowie w myśli politycznej Polskiej Zjednoczonej Partii Robotniczej, Wydawnictwo UMCS, Lublin 2013, ss. 416
}

\section{(c) $($ ) $\ominus$}

$\mathrm{N}$ akładem Wydawnictwa UMCS ukazała się kolejna książka Krystyny Wiesławy Trembickiej - historyk i politolog, której jednym z głównych zainteresowań badawczych jest myśl polityczna partii komunistycznych, w tym szczególnie Komunistycznej Partii Polski. Temat podjęty przez autorkę jest istotny, gdyż z upływem lat od upadku ustroju Polskiej Rzeczypospolitej Ludowej nauce potrzebne są szersze syntezy, pozwalające na formułowanie tez ogólnych, dotyczących określonych zjawisk zachodzących wewnątrz systemu politycznego PRL.

Praca została podzielona na pięć rozdziałów, w których autorka wyodrębniła od trzech do czterech podrozdziałów. Brak rozdrobnionej struktury jest więc jedną z zalet recenzowanej książki. W pierwszym rozdziale autorka przedstawiła doktrynalne podłoże „wrogości” w komunistycznej myśli politycznej. Podkreśliła m.in. dążenie komunistów do stworzenia państwa przyszłości i bezklasowego społeczeństwa. Uznała, że „kategoria wroga była immanentną cechą komunistycznego stylu myślenia" (s. 23). Wróg był ponadto potrzebny dla utrzymania opresyjnego systemu, więc $-\mathrm{w}$ jej ocenie - jednym z zadań służb specjalnych było tworzenie nowych wrogów. W rozdziałach drugim, trzecim i czwartym odniosła się do koncepcji wroga podmiotowego, przedmiotowego, jak również metod i środków walki z wrogiem. Wrogiem podmiotowym były jednostki, grupy i podmioty zbiorowe: państwa kapitalistyczne, przedsiębiorcy, chłopi, mniejszości narodowe i etniczne (szczególnie Kaszubi), opozycyjne partie, instytucje społeczne, jak Kościół katolicki. Wrogiem przedmiotowym były zaś zjawiska zachodzące wewnątrz systemu komunistycznego: herezje (czyli odstępstwa od aktualnie wyznawanej przez partię ideologii), strajki, ruchy kwestionujące system (w tym Solidarność) oraz eksperymenty ustrojowe podejmowane w bratnich państwach (np. na Węgrzech w 1956 r. i w Czechosłowacji w 1968 r.). Autorka kreatywnie zastosowała słowo „herezja”, zarezerwo- 
wane do koncepcji sprzecznych z ideologią Kościoła, do myśli komunistycznej. Wykazała, że za herezję był uznawany nie tyle pogląd sprzeczny z twierdzeniami Karola Marksa i Fryderyka Engelsa, ale niezgodny z aktualną doktryną partii komunistycznej, która była zależna od tego, jakie tezy głosił pierwszy sekretarz. Zasady wyznawane przez przywódców partii zmieniały się, więc wrogiem stawał się każdy, kto wyrażał wątpliwości co do decyzji podejmowanych przez najwyższe gremia partyjne. Tym sposobem - jak zauważyła autorka - wrogiem można było stać się „z dnia na dzień, żeby nie powiedzieć z godziny na godzinę" (s. 23). Ostatni rozdział został poświęcony znaczeniu i funkcjom, jakie pełnił „wróg” w komunistycznym systemie politycznym. Wróg pozwalał na uzasadnienie zmiany przywództwa, umożliwiał mobilizację społeczeństwa (np. przeciwko syjonistom), konsolidację partii, dawał możliwość kanalizowania niezadowolenia społeczeństwa, odwrócenia uwagi od bieżących problemów ekonomicznych i niskiej jakości życia. Był więc swoistym „wentylem bezpieczeństwa” dla rządzącej monopartii.

Autorka we wstępie przedstawiła przesłanki, jakimi kierowała się przy wyborze tematu pracy, oraz przyjęte przez siebie założenia badawcze. Polską Zjednoczoną Partię Robotniczą określiła mianem partii komunistycznej, a system polityczny PRL jako „bliższy modelowi totalitarnemu a nie jakiemukolwiek innemu” (s. 8). Analizując myśl polityczną pod kątem instytucji wroga politycznego, odwołała się do Carla Schmitta. Pisała o zjawisku wrogości w przestrzeni publicznej, gdyż - jak stwierdziła - partia polityczna, jeśli chce być skuteczna, musi dokonać oceny i klasyfikacji sceny politycznej na wrogów i sojuszników (zob. s. 9). Jest to naturalnie założenie sprawdzające się w takim reżimie politycznym, w którym zasadniczą rolę odgrywa konflikt, a nie kooperacja ugrupowań politycznych.

Autorka celnie wydzieliła zarówno wroga obiektywnego (realnie istniejącego, jak podziemie niepodległościowe), jak i potencjalnego, tj. takiego, którego władza mogła sobie wyobrazić dla realizacji swego celu zawłaszczenia społeczeństwa, bez względu na to, czy taki wróg realnie istniał. Tkwiła w tym swoista racjonalność działania osób zaangażowanych w budowę systemu i realizujących interesy komunistycznych elit. Autorka pisała także o sprzężeniu zwrotnym między rewolucją a wrogiem: rewolucja nie mogła obejść się bez wroga, który stale istniał, ale zmieniał się jego obraz 
w umysłach rewolucjonistów. Poza tym wróg uzasadniał sięganie do nadzwyczajnych środków represji (zob. s. 30).

Autorka wiele miejsca poświęciła na analizę polityki poszczególnych pierwszych sekretarzy: Bolesława Bieruta, Władysława Gomułki, Edwarda Gierka i Wojciecha Jaruzelskiego. Ukazała zależność przemian zachodzących w myśli PZPR od warunków zewnętrznych i woli suwerena, jakim była KPZR. W trakcie lektury książki nasuwa się porównanie marksizmu do religii, a dla przykładu samokrytyka byłaby odpowiednikiem publicznej spowiedzi (zob. s. 165). Trębicka wyjaśniła też stopniowy proces odchodzenia od doktryny marksistowskiej, co uzasadniało formułowanie wewnątrz partii w chwilach kryzysów postulatów powrotu do „czystego marksizmu”. Ukazała, jakim problemem dla rządzących były strajki robotników i w jaki sposób dążono do deprecjacji żądań pracowniczych (np. określaniem robotników mianem „bumelantów” i „chuliganów”). W przypadku, gdy danej instytucji społecznej nie dało się zniszczyć lub zastąpić podmiotem pełniącym rolę „pasa transmisyjnego” (jak wobec PSL-u, gdy wprowadzono ZSL), usiłowano tworzyć byty konkurencyjne (np. ruch księży patriotów).

Niewątpliwą zaletą książki jest pokazanie światopoglądowego modelu działania partii komunistycznej na przykładzie PZPR. Mankamentem są liczne powtórzenia i nawiązania do już omawianych wątków, jak np. wykorzystywania wroga do dokonania „skoku do przodu”. Zabrakło bardziej szczegółowego omówienia metod walki z wrogiem, dla przykładu porównania skrytobójstw działaczy PSL w latach czterdziestych z zabójstwami opozycjonistów w latach osiemdziesiątych. Nie w pełni wyczerpująco autorka poddała analizie zabójstwo księdza Jerzego Popiełuszki. Przez to czytelnik nie otrzymuje odpowiedzi na pytanie: czy - zdaniem autorki - był to normalny dla systemu, akceptowany przez Komitet Centralny PZPR zabieg, czy niekontrolowane działanie funkcjonariuszy służby bezpieczeństwa?

$\mathrm{Na}$ pochwałę zasługuje strona redakcyjna pracy, poprawność formalna i obszerność bibliografii, gdyż autorka sięgnęła do źródeł myśli komunistycznej (dzieł Marksa, Włodzimierza Lenina i Józefa Stalina), materiałów archiwalnych i źródłowych (uchwał, sprawozdań, przemówień pierwszych sekretarzy), publikacji zwolenników systemu (przede wszystkim tekstów periodyku „Z Pola Walki”), prac specjalistycznych (np. odnośnie do spółdzielczości) i regionalnych (do kolektywizacji rolnictwa). Brakowało recen- 
zentowi opracowań z zakresu historii gospodarczej Polski Ludowej, ale tematyka nacjonalizacji oraz walki ze spekulacją była jednym z wielu wątków poruszonych w pracy, co w pewnej mierze uzasadnia pominięcie prac z tej dziedziny.

Podsumowując, recenzent pragnie wyrazić pogląd, że omawiana praca Krystyny Wiesławy Trembickiej niewątpliwie stanie się ważną pozycją dla osób zainteresowanych dziejami myśli politycznej PZPR.

Karol Dąbrowski (Ryki) 